„Kwartalnik Filmowy” nr 112 (2020)

ISSN: 0452-9502 (Print) ISSN: 2719-2725 (Online)

https://doi.org/10.36744/kf.394

(c) Creative Commons BY-NC-ND 4.0

\title{
Karolina Sikorska
}

Uniwersytet Mikołaja Kopernika

https://orcid.org/o0oo-0001-9947-6516

Sandra Frydrysiak

SWPS Uniwersytet Humanistycznospołeczny

https://orcid.org/oooo-0001-6929-6338

\section{Po stronie swoich bohaterek. Feministyczny dokument filmowy w Polsce w drugiej dekadzie XXI wieku}

Słowa kluczowe:

feministyczny

film dokumentalny; wywiad pogłębiony; film interwencyjny; herstoria; siostrzeństwo; film edukacyjny

\begin{abstract}
Abstrakt
Autorki analizują z perspektywy feministycznej cztery polskie filmy dokumentalne (Strajk matek, reż. M. Maciejewska, M. Malinowska, 2011; Solidarność wedtug kobiet, reż. M. Dzido, P. Śliwowski, 2014; Strajk kobiet trwa, reż. M. Malinowska, 2018; Siłaczki, reż. M. Dzido, P. Śliwowski, 2018), dostrzegają obecne w nich wezwania do przeobrażania rzeczywistości społecznej i traktują jako przykłady „gatunku walczącego". Ten zaś jest postrzegany w artykule jako rodzaj doświadczenia społecznego, w którym na pierwszy plan wysuwa się konieczność solidarnej walki o lepsze życie, widoczność w sferze publicznej oraz kolektywne uznanie wartości, historii czy praktyk istotnych dla określonych wspólnot kobiecych. Zastanawiając się nad różnymi wymiarami feministycznego dokumentu filmowego - interwencyjnym, herstorycznym, zaangażowanym i edukacyjnym - autorki pokazują, w jaki sposób praca nad filmem staje się również działaniem na rzecz polskiego ruchu kobiet.
\end{abstract}


Dagmara Rode, przyglądając się polskim dokumentom feministycznym, tworzonym głównie w pierwszej dekadzie XXI w., wskazuje rozmaite strategie autorskie zaświadczające o przynależności omawianych przez nią utworów do tradycji ruchu feministycznego oraz wpisujące je w ramy zaangażowanego filmu dokumentalnego. Twórcy omawianych przez nią filmów pisza historię polskiego ruchu feministycznego ${ }^{1}$. Naszym celem jest rozwinięcie zagadnień podjętych przez Rode. Podobnie jak badaczka, chcemy nie tyle pisać historię polskiego dokumentu feministycznego, ile wyłuskać z wybranych przez nas filmów ${ }^{2}$ te elementy, które świadczą o ich charakterze emancypacyjnym. Innymi słowy, przyglądamy się wybranym produkcjom analizując obecne w nich wezwanie do przeobrażania rzeczywistości społecznej. Co więcej, wierzymy, że feministyczny dokument filmowy może być potraktowany jako narzędzie w walce o artykulację i zmianę szczególnego sposobu życia (particular way of life), który za Raymondem Williamsem włączamy do rozważań o kulturze jako dziedzinie obejmującej pewne znaczenia i wartości odnoszące się zarówno do sztuki czy nauki, jak i do instytucji (społecznie zorganizowanych form życia) i zwyczajnych zachowań .

Feministyczne dokumenty filmowe jako część polskiego ruchu feministycznego oddziałują na rzeczywistość, w której powstają i której dotyczą; komentują ja, a niekiedy mają nawet wobec niej charakter interwencji. Rzeczywistość społeczna podlega rozmaitym przeobrażeniom, uwidacznia problemy i kwestie dotąd nieporuszane czy wcześniej słabo rozpoznane. Te nowe okoliczności stają się okazją do zamanifestowania idei, przedyskutowania w nowym świetle określonych problemów i zainicjowania zmian.

Druga dekada XXI w. w Polsce w znacznym stopniu została naznaczona przez katastrofę smoleńska, a w konsekwencji coraz wyraźniejszą obecność w dyskursie publicznym kwestii związanych z funkcjonowaniem społeczeństwa polskiego jako narodu. Po 2010 r. coraz mocniej zaczęły rysować się spory światopoglądowe dotyczące pojęcia narodu i jego filarów, czyli Kościoła katolickiego, polityki historycznej czy instytucji rodziny opartej na tradycyjnych rolach genderowych ${ }^{4}$. Był to także czas dyskusji o polityce migracyjnej Polski (co wiąże się z tzw. kryzysem uchodźczym panującym od 2015 r. ${ }^{5}$ ) oraz zwiększonego zainteresowania obywateli i obywatelek kraju jego instytucjami w wyniku ich postępującego rozkładu (oświata, opieka społeczna, służba zdrowia), będącego z kolei w znacznym stopniu efektem neoliberalnych polityk gospodarczych. Wymienione procesy (jak i wiele innych, związanych np. z upowszechnianiem się technologii medialnych) wpływające na życie społeczne $\mathrm{w}$ Polsce stały się tłem kwestii poruszanych $\mathrm{w}$ interesujących nas filmach dokumentalnych, szczególnie istotnych z perspektywy feministycznej.

W tej perspektywie zostają zarzucone dążenia do obiektywizmu traktowanego jako rygorystyczne próby oddania rzeczywistości w sposób bezstronny czy też uwzględniający wszystkie punkty widzenia ${ }^{6}$. Taka analiza wymaga szczególnej uwagi i ostrożności przy wyznaczaniu dyrektyw określających kształt świata przedstawionego czy sposób konstruowania opowieści filmowej. Chodzi m.in. o brak zaufania do konwencji realizmu, wedle której film jest traktowany jako „okno na świat" ${ }^{\prime}$. Feministyczny dokument filmowy jest dla nas niefikcjonalną wypowiedzią opierającą się na określonej perspektywie, mającą prowadzić - pośrednio lub bezpośrednio - do przeobrażeń rzeczywistości społecznej przez zmianę sposobów myślenia, postrzegania i wartościowania zjawisk, sytuacji oraz 
postaci. Jego cechą jest także autorefleksyjność, zacieranie granic między sferą publiczną i prywatną czy budowanie przez autorki i autorów opartej na empatii relacji z bohaterami i bohaterkami. Sam "gatunek" jest dla nas formą doświadczenia społecznego, to zarówno tekst wizualny, jak i sposób, w jaki funkcjonuje on w dyskursie publicznym (istotne są nie tylko same filmy, ale także wypowiedzi twórców i protagonistów oraz konteksty kulturowe, w których filmy te funkcjonują).

Analizy Rode poświęcone polskim dokumentom feministycznym chronologicznie kończą się na filmie Strajk matek (reż. Magdalena Malinowska, Małgorzata Maciejewska, 2011) oraz na zapowiedzi znajdującej się wówczas w fazie produkcji Solidarności według kobiet (reż. Marta Dzido, Piotr Śliwowski, 2014). W niniejszym artykule prezentujemy możliwość walki o nowe znaczenia w filmach Magdy Malinowskiej - Strajk matek, Strajk kobiet trwa (2018) oraz Marty Dzido i Piotra Śliwowskiego - Solidarność według kobiet, Siłaczki (2018).

\section{Metodologia}

Wybranym filmom dokumentalnym przyglądamy się z perspektywy feministycznej, z jednej strony sięgając do rozważań filmoznawczych takich badaczek, jak Teresa de Lauretis ${ }^{9}$, Monika Talarczyk ${ }^{10}$ czy Małgorzata Radkiewicz $^{11}$, z drugiej zaś interpretując tę twórczość w odniesieniu do koncepcji feministycznych z obszaru kultury, historii i społeczeństwa Nancy Fraser ${ }^{12}$, Silvii Federici ${ }^{13}$, Joan Wallach Scott ${ }^{14}$ czy Marii Solarskiej ${ }^{15}$. Ponieważ jednak - zgodnie z wcześniejszą deklaracją staramy się wskazać współczesną specyfikę feministycznego dokumentu filmowego, traktując go jako rodzaj doświadczenia społecznego (a nie tylko jako materiał wizualny), sięgamy również po formułę wywiadu pogłębionego, prezentując rozmowy z twórcami ${ }^{16}$. Ma to na celu zrozumienie kontekstu oraz uzmysłowienie szczególnych sposobów odbioru rzeczywistości przez nasze rozmówczynie i rozmówcę ${ }^{17}$. Starałyśmy się nie tylko dać im możliwość zaprezentowania ich punktu widzenia, ale także wyjaśnić własny sposób rozumienia niektórych kwestii (np. dokumentu feministycznego), a więc umożliwić negocjowanie znaczeń. Wywiady, zaplanowane jedynie częściowo, przypominają miejscami „narracyjne kolaże" - łamią porządek chronologiczny zdarzeń i prezentują historie, które nie muszą być związane sekwencjami przyczynowymi ${ }^{18}$.

Feministycznie zorientowana analiza filmu to w naszym przekonaniu także analiza kulturoznawcza, która sięga po narzędzia myślenia krytycznego, nie unika złożoności, umieszcza obrazy, reprezentacje i dyskursy w zróżnicowanych kontekstach społecznych. Kulturoznawcze i feministyczne badania filmu dokumentalnego domagają się sproblematyzowania sytuacji kobiet, których historie zostają opowiedziane, ale i urefleksyjnienia pozycji autorek i autorów ukazujących swoje bohaterki w określony sposób. Dlatego w naszych rozważaniach podążamy również za propozycją Virginii Olesen, dla której badania feministyczne problematyzuja (...) ugenderowione instytucje oraz struktury materialne i historyczne, które je organizują ${ }^{19}$. Dlatego właśnie tak dużo miejsca poświęcamy rozpoznaniu kategorii kształtujących myślenie i praktykę interesujących nas filmowców. Chodzi nam w tym wypadku raczej o pokazanie społecznego i politycznego charakteru wybranych utworów aniżeli ich analizę formalną prowadzoną z użyciem terminów z obszaru estetyki. 
Sięgnęłyśmy po omawiane tu filmy z kilku powodów. Po pierwsze, stanowią one interesujące i - naszym zdaniem - dość istotne świadectwa zmian zachodzących współcześnie w społeczeństwie polskim. Po drugie, zafascynowały nas historie w nich opowiedziane. Po trzecie, uważamy, że problemy poruszone przez ich twórców powinny być szeroko dyskutowane, a nasz szkic winien stać się jednym z feministycznych i kulturoznawczych głosów w tej dyskusji.

\section{"Gatunek walczący"}

Feministyczny dokument filmowy jest wart omówienia z jeszcze jednego, jakże ważnego powodu. Jest nim jego rola w kobiecej emancypacji. Szczególna relacja między dokumentem filmowym a feminizmem wynika z potrzeby innej, niemęskocentrycznej reprezentacji, alternatywnej kultury politycznej i wzajemnego edukowania się kobiet. Pierwsze feministyczne filmy dokumentalne na Zachodzie powstawały $\mathrm{w}$ latach 60. i 70. XX w., w ramach działaności tzw. grup uświadamiających. Były to kolektywy kobiet, które najczęściej wyrastały z antywojennych ruchów lewicowych w Stanach Zjednoczonych. Zdobyte wcześniej doświadczenia filmowe kobiety postanowiły wykorzystać na rzecz ruchu feministycznego ${ }^{20}$.

Na gruncie rozwijającej się od lat 70. feministycznej teorii filmu rozpoznanie formy dokumentalnej jako skutecznego narzędzia feministycznego aktywizmu nie nastąpiło jednak od razu. Początkowo dominowała perspektywa psychoanalityczna zorientowana na kino głównego nurtu. Skupiano się na uprzedmiotawiających przedstawieniach kobiet i ich ciał, męskim spojrzeniu, wojeryzmie ${ }^{21}$; podkreślano potrzebę tworzenia filmów w opozycji do „męskiego kina” z Hollywood ${ }^{22}$. Kino kobiet $^{23}$ miało być sprzężone $\mathrm{z}$ awangardą i dalekie od realizmu, co się wiązało z oczywistym sceptycyzmem wobec form dokumentalnych.

W debatach wokół przydatności filmu dokumentalnego dla ruchu feministycznego wybrzmiał głos Claire Johnston. Rozmyślając nad strategiami dla kina kobiecego, badaczka czerpała z teorii filmu bazującej m.in. na krytyce realizmu Waltera Benjamina. Punktowała więc estetykę kobiecych dokumentów za naśladowanie technik telewizyjnych i cinema vérité, które udawały rzeczywistość i nie poddawały krytyce samego medium. Przedstawianie historii kobiet bez żadnej interwencji ze strony twórczyń filmu było według Johnston poddaniem się opresyjnemu przekonaniu o rzekomej neutralności i niewinności oka kamery. Badaczka nawoływała więc do porzucenia takiego sposobu myślenia i wypracowania nowego języka i znaczeń, które zamiast postaw pasywnych promowałyby ducha rewolucyjnego ${ }^{24}$. W problematyzowaniu „udawania rzeczywistości” przez filmy z nurtu cinema vérité i kina bezpośredniego Johnston wtórowała Eileen McGarry, która wskazywała, jak część twórczyń, świadomych nietransparentności realizmu, z powodzeniem korzysta z anty-realistycznych zabiegów, by lepiej pokazać ucisk kobiet ${ }^{25}$. Psychoanalityczna dominacja w feministycznej krytyce filmowej nie pozwoliła jednak rozwinąć się refleksji nad innymi strategiami dokumentalnego kina kobiecego ${ }^{26}$.

Impulsem do zmiany był z pewnością interwencyjny esej Julii Lesage z 1978 r. Autorka podkreślała w nim, że dokument feministyczny to forma filmowa stanowiąca część inicjatywy politycznej, jaką był ówczesny ruch kobiet; korzystanie $\mathrm{z}$ tradycyjnych strategii realistycznych postrzegała $\mathrm{z}$ kolei jako przemyślane 
i słuszne. Pozwalało ono bowiem dotrzeć do instytucji - edukacyjnych, religijnych, związkowych itp. - które nie dawały szans na zapoznanie się z treściami feministycznnymi. Lesage postrzegała zatem film dokumentalny przede wszystkim jako narzędzie kształtowania świadomości zbiorowej, która finalnie miałaby doprowadzić do zmiany społecznej"27.

Jak pokazuje historia feministycznych dokumentów filmowych (w tym omawiane przez nas przykłady), stały się one przede wszystkim - zgodnie z wizją Lesage - sposobem feministycznej walki o postulaty ważne dla kobiet, swoistym "gatunkiem walczącym”. Celem tej walki jest widzialność problemów istotnych z kobiecego punktu widzenia oraz kobieca sprawczość. Do dziś dokumenty feministyczne wskazują też, że to, co prywatne jest zarazem polityczne, traktują priorytetowo kobiecą podmiotowość (co dotyczy i autorek, i widzek) oraz tworzą reprezentacje kobiet jako podmiotu politycznego ${ }^{28}$. Co więcej, według statystyk kobiety miały i mają łatwiejszy dostęp do filmu dokumentalnego niż fabularnego ${ }^{29}$. Sprawniejsze pokonywanie celuloidowego sufitu ${ }^{30} \mathrm{w}$ dokumencie wiąże się przede wszystkim z mniejszym budżetem, który jest potrzebny do realizacji projektu. Z kolei - jak wynika z naszych wywiadów - trudności w dostępie do sprzętu rejestrującego, profesjonalnej obsługi na planie czy wyspecjalizowanych narzędzi postprodukcji powodują paradoksalnie zwiększenie swobody twórczej. Nie chcemy przez to powiedzieć, że niskie budżety z założenia ją gwarantują; chodzi raczej o to, że czasem autorkom nieuwikłanym w zależności instytucjonalne czy niemającym zobowiązań dotyczących rozliczania dotacji łatwiej podejmować tematy "niewygodne” i niewpisujące się w dominujący dyskurs polityczno-historyczny.

\section{Dokument interwencyjny jako walka o poprawę warunków życia}

Zrealizowany przez Magdę Malinowską i Gośkę Maciejewską film Strajk matek opowiada o walce, jaką (włącznie z protestem głodowym) podejmowały od 2008 r. kobiety w Wałbrzychu, by móc pozostać wraz z rodzinami w zajętych przez siebie mieszkaniach wcześniej będących pustostanami. W nagraniach Maciejewskiej i Malinowskiej widzimy kilka kobiet, które opowiadają o tym, dlaczego zostały zmuszone do zajmowania pustostanów, jak o nie walcza, jaka jest ich sytuacja rodzinna i zarobkowa, jak zostały potraktowane przez władze miasta oraz co sprawiło, że zaczęły się organizować i wspierać. Już po realizacji filmu autorki zwracały uwagę na konieczność pokazania walczących kobiet w inny sposób, aniżeli dotąd prezentowały je media. To też konieczność sprzeciwu wobec ich stygmatyzowania i obarczania całkowitą odpowiedzialnością za sytuację, w której się znalazły. Jednak celem tego przedsięwzięcia, które zostało określone przez twórczynie jako badania zaangażowane, partycypatywne, nie było jedynie zaprezentowanie sytuacji społecznej protagonistek. Duże znaczenie miało także ukazanie politycznego charakteru podejmowanych przez nie działań i oddanie im sprawczości: Przeprowadzajac wywiady miałyśmy na uwadze, że nie mają one ograniczyć się do socjologicznego opisu warunków życia w Wałbrzychu. Rozpoczynały one zbiorowy, polityczny proces majacy na celu przemyślenie form samoorganizacji pracowników i bezrobotnych, rozszerzenie wspólnej walki z różnymi formami opresji i wyzysku oraz wniesienie 
tych doświadczeń do ogólnej dyskusji nad możliwościami i ograniczeniami szeroko rozumianej walki klasowej, rozumianej także jako walka z patriarchalnym uciskiem ${ }^{31}$.

Zarówno sam dokument, jak też towarzyszące mu działania inicjowane i współpodejmowane przez obie autorki doskonale wpisują się w ramy „badań w działaniu" w wersji, którą - za Stephenem Kemmisem - możemy nazwać krytyczną. Inicjatywy te mają na celu stuszne działanie ( $w$ znaczeniu moralnym) ${ }^{32}$ oraz interweniuja w dokonująca się kolektywna historię przez działanie badawcze skupiające się na analizie podzielanej rzeczywistości w celu jej przekształcenia oraz przekształcenia jej w celu zbadania ${ }^{33}$. Obie autorki są zresztą świadome tego procesu i podchodzą do przedsięwzięcia autorefleksyjnie i autokrytycznie. Ich pracę charakteryzowała od początku także otwartość oraz pewna gotowość do reagowania na zmieniającą się sytuację - przekonanie, że dokument partycypacyjny traktuje ukazywane i dzielone doświadczenia jako pewną wiedzę, którą należy przyjąć i potraktować poważnie ${ }^{34}$.

W przywołanym tekście reżyserki podnoszą też kwestie współpracy i zgody ukazywanych przez nie kobiet na prezentację zmontowanego materiału. Co istotne, odrzucają one nadmierny emocjonalizm i sensacyjność, chcąc - jak same mówią uszanować uczucia i zdanie ludzi, z którymi wspótpracuja, zaś ból, który objawiat się w sytuacji, kiedy kobiety mówity o swoich dzieciach, czy śmierci kogoś bliskiego, był częścia ich intymności i nie potrzeba było nim epatować, żeby unaocznić materialne warunki ich życia i powody protest $u^{35}$. Położenie akcentu na sprawczość kobiet walczących o godne warunki życia jest elementem podejścia feministycznego. Magdalena Grabowska proponuje takie rozumienie sprawczości, które odrzuca prosty podział na zachowania proaktywne i reaktywne i odnosi tę kategorię do możliwości działania uwarunkowanego kontekstami społeczno-kulturowymi ${ }^{36}$. Obie reżyserki, podobnie jak Grabowska, podkreślaja, że sprawczość jest rodzajem doświadczenia i praktyką uzależnioną zarówno od dostępnych w danym czasie zasobów (materialnych, symbolicznych, ideologicznych), jak i nawiązanych relacji czy siły, którą w danym czasie dysponuje jednostka bądź społeczność. Matki z Wałbrzycha są sprawcze, bo redefiniują nie tylko własną podmiotowość, ale i poszerzają przestrzeń debaty publicznej.

Strajk matek postrzegamy jako interwencję, film dokumentalny, który powstał, by zmienić sytuację kobiet walczących o godne warunki życia. I choć - jak pisały Maciejewska i Malinowska - tymczasowy i „zewnętrzny” (obie dojeżdżały do Wałbrzycha, nie były jego mieszkankami) charakter tej interwencji jest jej słabością to zmieniła ona częściowo sposób myślenia i działania zaangażowanych w tę walkę osób oraz dziennikarzy czy urzędników. Sytuacja kobiet walczących o mieszkania zyskała szerszą uwagę społeczną: Film umożliwił także nagłośnienie konfliktu w innych miejscach Polski, a także świata. Jako jeden z nielicznych materiatów przywracajacych debatę o powiązaniach płci, klasy i ubóstwa, wywotał także poruszenie w polskim środowisku feministycznym. Kobiety z Wałbrzycha stały się dla wielu inspiracja do walki i działania ${ }^{37}$.

Dokument, towarzyszące mu rozmowy i spotkania, a także wspólny montaż przyczyniły się do nowego określenia problemów, interesów oraz układu sił w porządku społecznym. Kobiety przestały być postrzegane jako roszczeniowe, okazały się silne i sprawcze. Dominujący system wartości zbudowany na neoliberalnej prywatyzacji sektora publicznego, prawie własności, wierze $\mathrm{w}$ bezinteresowną i sprawiedliwą służbę władz miasta oraz równy dostęp do pracy (a także w możliwość utrzymania się za otrzymywane wynagrodzenie każdego, kto podejmie pracę), choć 
nie został zrewolucjonizowany, to jednak podany w wątpliwość, zarówno z uwagi na (rzekomą) neutralność, jak i użyteczność społeczną.

Jako zaangażowany dokument interwencyjny film Maciejewskiej i Malinowskiej nie ukazuje rzeczywistości społecznej w całości i ze wszystkich dostępnych perspektyw. Słyszymy i widzimy w nim przede wszystkim kobiety, które opowiadają o swoich doświadczeniach. Niekiedy pojawiają się także nagrania dotyczące wcześniejszych wypadków, zdjęcia z protestów przed urzędem miasta oraz obrazy ulic i budynków. Celowym zabiegiem jest niepokazywanie adwersarzy politycznych, wobec których są wysuwane roszczenia. Autorki Strajku matek stoją wyraźnie po stronie swoich bohaterek.

Zapytana o kwestię obiektywizmu w filmie dokumentalnym Magda Malinowska mówi, że nie chce robić filmów, które byłyby obiektywne. Z jednej strony wynika to z podważenia samej kategorii obiektywizmu ${ }^{38}$, z drugiej reżyserka (odpowiadając niejako na wezwanie Jaya Ruby'ego) staje się interpretatorką, która niejako przyswoiła społeczny obowiazek niebycia obiektywna dokumentalistka ${ }^{39}$. Twórczyni podkreśla, że ważna jest jej osobista perspektywa: Ja chcę przekazać taka wiedzę, perspektywe, jaka ja mam - $i$ moje środowisko, i osoby, które robia ze mna ten film. (...) Oczywiście to, że bym chciała, żeby sytuacja pracowników się polepszyła, to, że działamy na rzecz zmiany kapitalistycznych stosunków, to musi wybrzmieć w tych filmach. Ja jestem po stronie pracowników, te filmy maja nam stużyć. Tamta strona [pracodawcy] ma i tak znacznie więcej narzędzi, które może wykorzystywać (W_MM).

W Strajku matek perspektywa ta ujawnia się także w komentarzu z offu, kiedy słyszymy o przeobrażeniach gospodarczych Wałbrzycha, które uderzyły w kobiety, a w szczególności w matki. Możemy to z łatwością odnieść właśnie do znanego hasła drugiej fali feminizmu głoszącego, że prywatne jest polityczne. Intymne historie kobiet umieszczone w szerszym kontekście walki z prywatyzacją i feminizacją ubóstwa, mają się stać zachętą do dalszego działania. Film Maciejewskiej i Malinowskiej łączy rejestrację określonej sytuacji z próbą zrozumienia mechanizmów niesprawiedliwości społecznej, ujawniających się w określonym czasie i miejscu; jest wołaniem o „sprawiedliwe relacje reprezentacji”, równouprawnienie i możliwość decydowania o kształcie własnej wspólnoty ${ }^{40}$. Uzyskana dzięki filmowym środkom wyrazu widoczność matek i osób bezrobotnych zwiększa szansę na poprawę ich warunków życia i naprawę dotykających je krzywd.

\section{Dokument herstoryczny jako walka o polityczną widoczność kobiet}

Solidarność według kobiet opowiada historię przewrotu w Polsce z perspektywy kobiet, akcentując ich aktywny udział w tym wydarzeniu. Premiera filmu odbyła się w 2014 r., czyli w czasie, gdy w Polsce toczyła się dyskusja o tzw. polityce historycznej, mającej na celu wzbudzanie i wzmacnianie postaw patriotycznych, utrwalanie w pamięci narodowej konkretnej wizji przeszłości, ale i przekazywanie wzorców zachowań płciowych, korespondujących z określoną wersją patriotyzmu.

Dokument Dzido i Śliwowskiego jest wyrazem sprzeciwu wobec nierównościowych strategii obecnych w dominujących narracjach o historii, odzyskuje zapomnianą, a często celowo pomijaną opowieść o udziale kobiet w życiu politycznym i wpisuje się w logikę zwrotu herstorycznego ${ }^{41}$. Przewrotny neologizm używany od 
czasów drugiej fali feminizmu odnosi się do her-story (jej historii/opowieści), podając jednocześnie w wątpliwość obiektywizm his-story, czyli historii pisanej z perspektywy mężczyzn i o mężczyznach, pretendującej do wiedzy uniwersalnej i jedynej prawdziwej. W filmie poznajemy zapomniane i nieobecne $\mathrm{w}$ dzisiejszej polityce działaczki ruchu związanego z Niezależnym Samorządnym Związkiem Zawodowym „Solidarność", którego aktywność przyczyniła się do upadku PRL. Bohaterki opowiadają o swoim udziale w walce o niepodległość: uczestnictwie w strajkach, tworzeniu wizji przyszłości i budowie podziemia oraz o tym, jak były więzione i szantażowane. Film realizuje zatem jeden z głównych celów badaczek herstory, którym jest odkrywanie i pisanie nieistniejącej w sferze publicznej historii kobiet oraz włączanie jej do głównego nurtu narracji historycznych ${ }^{42}$.

W duchu historycznej narracji Dzido i Śliwowski prezentują materiały archiwalne (zdjęcia i filmy), w których widzimy bohaterki podczas działań na rzecz wolnej Polski - wcześniej zapomniane i anonimowe, teraz zyskują imiona i nazwiska. Proces odzyskiwania tożsamości kobiet wykluczonych z oficjalnej historii wymagał wytężonej pracy, której wcześniej nikt nie wykonał. W trakcie realizacji dokumentu twórcy chcieli dowiedzieć się, dlaczego tak się stało. Podobno podczas przełomowego strajku w Stoczni Gdańskiej w 1980 r. na okalającym ją murze widoczne było graffiti: Kobiety, nie przeszkadzajcie nam, my walczymy o Polskę. Symboliczne, seksistowskie hasło przekonuje do dziś, jakoby kobiety nie odegrały znaczącej roli w historii zrywu solidarnościowego. Slogan ten przedarł się do świadomości zbiorowej, odbierając kobietom sprawczość polityczną ${ }^{43}$. Dzido i Śliwowski pokazują jednak za pomocą materiałów archiwalnych, pierwszoosobowych narracji oraz testymoniałów bohaterek ówczesnych wydarzeń, że kobiety miały decydujący wpływ na ich przebieg i sukces. Oprócz przypomnienia, że to zwolnienie z pracy kobiety, Anny Walentynowicz, stało się głównym impulsem do buntu, film zawiera wskazówki dotyczące (zupełnie nieobecnej w dominujących przekazach historycznych) roli kobiet w kontynuacji strajku. Gdy po kilku dniach negocjacji z władzami Stoczni Gdańskiej doszło do ustanowienia podwyżki płac robotników, Lech Wałęsa obwieścił zakończenie strajku. Alina Pieńkowska opowiada w filmie, że na dziedzińcu stoczni znajdowały się wtedy jednak również osoby z innych zakładów pracy, które pozostały „,z niczym”. To dzięki inicjatywie kobiet bramy stoczni zostały zamknięte i zapadła decyzja o rozpoczęciu strajku solidarnościowego. Historię tę poznajemy dzięki niemal detektywistycznemu śledztwu Marty Dzido, która przeglądając w archiwum spoczywające tam od dekad materiały filmowe opatrzone napisem „Solidarność 80 - materiały produkcyjne odrzucone", widzi na taśmie nieznaną kobietę stojącą nad tłumem robotników i postanawia odkryć, kim ona jest. Historia poszukiwań Ewy Ossowskiej stanowi jedną z głównych osi fabularnych filmu.

W Solidarności wedtug kobiet na próżno szukać wszechwiedzącego narratora męskiego. Film dedykowany jest symbolicznej „,córce Solidarności”, w którą wciela się Marta Dzido (urodzona w 1981 r.) i to ona przejmuje rolę narratorki, wprowadzając nas w rozmowy z bohaterkami i ujawniając własny (feministyczny) punkt widzenia. I tak w filmie głos mają tylko kobiety, bo to one - zdaniem Dzido - zostały "wygumkowywane" z historii i to ich perspektywy nie znamy. Autorom zależało zatem, by nie tyle przedstawić historię z różnych perspektyw, ile wyeksponować i wzmocnić perspektywę kobiet, które nigdy nie miały okazji opowiedzieć „swojej prawdy". Podejście to cechuje się wrażliwością herstoryczną oraz wpisuje w kon- 
cepcję wiedzy usytuowanej Donny Haraway. Praktyka wytwarzania wiedzy jest według teoretyczki zawsze umiejscowiona w rozmaitych kontekstach (podobnie zresztą jak głos autora/autorki w tekście), fragmentaryczna i subiektywna. Właśnie dzięki świadomości owych kontekstów i cząstkowości ustanawiamy jej „racjonalność" ${ }^{44}$. Wiedza też jest tworzona zawsze z czyjejś perspektywy, zostaje społecznie skonstruowana, tj. naznaczona płcia, klasa, orientacją polityczną i innymi kategoriami. W ramach praktyki feministycznej Haraway zaleca zatem stronić od takiego jej wytwarzania, które esencjalizuje i uogólnia. Podobny przekaz płynie z dokumentu Dzido i Śliwowskiego.

Twórcy odzyskują historię kobiet, ale też przekształcają symbolikę narodową. Na okładce płyty DVD, jak i w samym filmie pojawia się subwersywnie zmieniony plakat promujący pierwsze, częściowo wolne wybory w 1989 r. Wizerunek aktora Gary'ego Coopera, znajdujący się pośrodku oryginalnego plakatu Tomasza Sarneckiego, w pracy Sanji Iveković (Niewidzialne kobiety Solidarności, 2009) zostaje zastąpiony sylwetką kobiety. Jest to wyraz oporu wobec dominujących maskulinistycznych wizji sprawczości politycznej. Walka o polityczną widoczność kobiet to także jeden z celów twórców filmu. Impulsem do opowiedzenia o bohaterkach związanych z „Solidarnością” stał się fakt, że przestały być one rozpoznawane w mediach głównego nurtu. Piotr Śliwowski tłumaczy: 10 kwietnia 2010 roku wydarzyła się katastrofa smoleńska i tam też był taki wyzwalacz, jak zobaczyliśmy podpis: "Anna Walentynowicz - osoba towarzyszaca". I to wtedy nas wzmocniło w tym przekonaniu, $\dot{z}$ e ta historia się rozmywa, że traci kontury, że dziś Anna Walentynowicz jest osoba towarzyszaca i że na naszych oczach idzie to w jakimś niezrozumiałym kierunku (W_MDPŚ).

Film przywraca kobietom należne im miejsce w historii „Solidarności”, prezentuje kobiece wzorce i autorytety młodemu pokoleniu, które może utożsamić się z narratorka, ale też spełnia inny ważny postulat herstoryczny - tworzy pamięć zbiorową i pracuje na rzecz tożsamości samych kobiet, bohaterek tej historii, uświadamiając im wagę ich własnej roli oraz motywując do dalszej walki o widoczność. Dokument pokazuje też, w jak niewielkim stopniu zasługi kobiet były doceniane przez inne kobiety działające w ruchu, a często przez nie same. Protagonistki mówia, że robity to, co trzeba było zrobić, a gdy zostają poproszone o wymienienie nazwisk innych działaczek, mają z tym trudność. W jednej z ostatnich scen słyszymy wypowiedź Janiny Jankowskiej, działaczki opozycji demokratycznej w okresie PRL, dziennikarki, autorki książki o liderach „Solidarności” ${ }^{45}$, w której nie znalazła się ani jedna rozmowa z przedstawicielkami ruchu. W trakcie spotkania z Dzido Jankowska sama dochodzi do wniosku, że kobiety zostały usunięte $z$ dominującej narracji, a ich zasługi nie były doceniane (także przez same kobiety).

Solidarność według kobiet oprócz tego, że spełniła funkcję uświadamiająca wobec części bohaterek, wpłynęła bezpośrednio na losy jednej z nich - Ewa Ossowska wróciła z emigracji i zmieniła swoje życie zawodowe i prywatne. Film możemy zatem potraktować również jako dokument interwencyjny, choć nie był świadomie planowany w ten sposób, zaś sami autorzy stronią od jednoznacznego klasyfikowania filmu. Śliwowski sugeruje, że jest on równościowy i sprawiedliwy, Dzido dodaje, że feministyczny, patriotyczny i historyczny. Można byłoby też określić go mianem filmu dokumentalnego w trybie uczestniczącym, który według Billa Nicholsa opiera się na swoistym dialogu między filmowcem a jego bohaterem/bohaterką i w którym wykorzystuje się usytuowane zaangażowanie, negocjowana interakcje 
i petne emocji spotkanie. Te jakości nadaja uczestniczacemu trybowi filmu dokumentalnego znaczacy urok, ponieważ łączy on najrozmaitsze obszary, od najbardziej osobistych po najbardziej historyczne. Faktycznie, często ów tryb pokazuje, jak te dwa bieguny przenikaja się, by wyprodukować reprezentacje historycznego świata z konkretnych perspektyw, które sa zależne $i$ zaangażowane 46 . Uważamy, że film Solidarność według kobiet ma również właściwości emancypacyjne, o których świadczą zarówno jego herstoryczny charakter, jak i sam sposób pracy przy nim. Ujawnia się w niej bowiem troska twórców o bohaterki (słuchamy ich swobodnych wypowiedzi, widzimy je w ich naturalnym otoczeniu). Dzido i Śliwowski wprawdzie nie pokazali swoim protagonistkom filmu przed premiera, ale - jak dowiedziałyśmy się podczas wywiadu - jeśli któraś poprosiła o wgląd w materiał i wycofała zgodę na publikację, zostało to uszanowane.

Herstorie, które - jak w cytowanym wywiadzie mówi Śliwowski - uzupetniaja powszechna narrację historyczna, powstały zatem z odpowiednią (jak sądzimy - feministyczną) wrażliwością i przypomniały o wielkiej sprawczości politycznej kobiet w czasach solidarnościowej walki o niepodległość. Film o bohaterkach „Solidarności" zaświadcza, że choć one same są dziś rzadko obecne w dyskursie politycznym, to $\mathrm{w}$ czasie przewrotu solidarnościowego były bardzo aktywne i wpłynęły na bieg historii ${ }^{47}$. Rzucając światło na te wydarzenia, Dzido i Śliwowski podkopują ugruntowane narracje, przyczyniając się do przywracania kobietom widoczności w polityce i historii.

\section{Dokument zaangażowany jako walka o nowe siostrzenstwo}

W zrealizowanym przez Magdę Malinowską w 2018 r. filmie pt. Strajk kobiet trwa chodzi już nie tyle o badania społeczności i walki na jej rzecz, ile współpracę z nią. Celem jest utożsamienie z roszczeniami prezentowanej grupy kobiet, aktywne jej wsparcie i wypracowanie nowego sposobu rozumienia (kobiecej) solidarności. Malinowska, opowiadając o kontynuacji działań podjętych w Wałbrzychu ${ }^{48}$, tym razem na rzecz pracownic i pracowników specjalnej strefy ekonomicznej położonej na obrzeżach miasta, wspomina w wywiadzie, że nie mogła zaangażować się w działania $\mathrm{w}$ takim stopniu, jak chciała, ponieważ w tym czasie wspierała już dziewczyny z poznańskich żłobków. Oznacza to nie tylko, że towarzyszy im z kamera, ale przede wszystkim uczestniczy w prowadzonych przez nie działaniach pracowniczych: od sporu zbiorowego z pracodawca, przez liczne demonstracje i pikiety, po realizację filmu traktowanego - ponownie - jako narzędzie zmiany rzeczywistości. Jej zaangażowanie powoduje, że walczące kobiety zaczynają jej ufać. Osoby, które opowiadają Malinowskiej o swojej trudnej sytuacji i walce, wiedza, że dla niej samej jest to także sprawa ważna i że nie zostaną przez nią zlekceważone ani wykorzystane. Twórczyni, która jest członkinią związku zawodowego „Inicjatywa Pracownicza”, okazuje się przez swoje działania wiarygodna nie tylko dla osób, z którymi pracuje przy filmie, lecz także dla odbiorców. Realizując dokument o strajkujących pracownicach poznańskich żłobków, nie musiała wykonywać jakichś pogłębionych badań, bowiem znała dobrze ich położenie i często współdziała z nimi. Dlatego też Malinowska obrusza się, kiedy traktuje się ją jako autorkę (celowo, przez prawie rok od premiery filmu, która odbyła się w marcu 2018 r. w napisach końcowych nie figurowała jako reżyserka); dostrzega w formie dokumentalnej narzędzie służące 
poprawie warunków życia pracowników, a nie dzieło odsyłające do kategorii estetycznych i akceptuje zindywidualizowaną instancję autora jako „zło konieczne" (zgadzając się na takie określanie siebie tylko wtedy, gdy film jest przedmiotem dyskusji na spotkaniach wokół problemów kobiet, a ona sama występuje jako osoba odpowiedzialna za pracę nad nim). To odrzucenie podziału na twórczynię i bohaterki wynika także z szacunku dla odpowiedzialności pracownic żłobków za podejmowane przez nie działania. To one były ich autorkami, a Malinowska swą rolę osoby dokumentującej i komentującej określa jako drugorzędną: My im pomagaliśmy, ale odpowiedzialność i wszystkie konsekwencje, jakie mogły ponieść spadty na nie. Większość działań, które realizowaliśmy jako zwiazek, była ich pomystem lub była inspirowana ich pomystami, np. demonstracja w $2012 r .^{49}$ czy groźba strajku. To wszystko wychodzito od nich, a nie od nas. I też one byty przez to represjonowane, nie my, to jest ich historia, nie moja (W_MM). Jak wielokrotnie podkreśla twórczyni - film ma być instrumentem zmiany myślenia i działania, ma służyć ideom i praktykom, o których opowiada: Przez ten film chce pokazać, że to sa pracownice, które moga mówić za siebie, że maja doświadczenie, którym chca się dzielić, (...) że świat pracowniczy jest ciekawy, (...) że ma sporo swoich żądań, które sa do spetnienia i sa uzasadnione. To ma być rola tych filmów. A nie, wiesz, pokazywanie się na salonach: "A ja teraz zrobiłam film" (W_MM).

Malinowska jednocześnie widzi braki we własnym warsztacie filmowym i dostrzega konieczność ulepszenia swojej strategii dokumentacyjnej. Jednak nie chodzi tu o jakość wizualną jako wartość samą w sobie. Filmy muszą być dobre, by uczciwie pokazać rzeczywistość, o której opowiadają (nie powinny przykuwać uwagi niedostatkami warsztatowymi twórców) oraz by uszanować osoby, które zdecydowały się w nich pojawić. Twórczyni mówi o tym, odnosząc się do jednego ze swoich wcześniejszych projektów: W niedostateczny sposób okazałam im szacunek robiąc film, który nie jest dobry w każdym momencie. (...) Wydaje mi się, że pracownicy zastuguja na to, żeby te filmy byty jak najlepsze. Żeby oni byli w stu procentach usatysfakcjonowani $z$ tego, jak ten film wyglada, w każdej z tych możliwych sfer - czy estetycznej czy treściowej (W_MM).

Produkcja z 2018 r. skupia się na walce kobiet pracujących w miejskich przedszkolach i żłobkach, która zaczęła się w 2011 r. w Poznaniu. Zatrudnione na minimalne stawki pracownice, obciążone obowiązkami ponad siły, zmęczone i zdesperowane zaczynają bój o poprawę warunków pracy. Film otwiera scena z czarnego poniedziałku - ogólnopolskiego protestu przeciwko zaostrzeniu prawa do aborcji, który odbył się 3 października 2016 r. W jednym z ujęć widzimy pracownicę krzyczącą ze sceny do tłumu: Rząd chce, by rodziło się coraz więcej dzieci, ale czy one maja godne miejsca w żłobkach, godne miejsca w przedszkolach? Walczyłyśmy o to, aby miały godne warunki, ale miasto miało nas gdzieś. Pokazując na początku filmu o pracownicach żłobków jeden z czarnych protestów ${ }^{50}$, Malinowska wskazuje, że prawa kobiet to także prawa pracownicze. W systemie patriarchalnym, w którym żyjemy, kobiety są traktowane gorzej niż mężczyźni, zrzuca się na nie chociażby obowiązki związane z opieką nad dziećmi, osobami starszymi czy chorymi, co przekłada się na ich sposób zarobkowania oraz feminizację gorzej płatnych sektorów pracy i zawodów. Skutkiem ubocznym tego systemu opartego w wielu krajach, w tym także w Polsce, na neoliberalnych praktykach rynkowych, zorientowanych na akumulację kapitału kosztem polityki społecznej czy ekologicznej, jest także zjawisko feminizacji ubóstwa ${ }^{51}$. 
W filmie pojawiają się również sceny o charakterze objaśniającym, osądzajacym przeszłe zdarzenia ${ }^{52}$, np. kiedy przypomina się o konsekwencjach transformacji ustrojowej w postaci obrazów z fabryk, w których pracują kobiety, a głos z offu tłumaczy ich trudną sytuację. W roli „tłumaczki” występuje filozofka Silvia Federici. Opowiada ona o powiązaniach bezpłatnej pracy domowej kobiet z kapitalizmem. Tu, jak i w innych wystąpieniach czy tekstach, Federici zwraca uwagę na znaczenie pracy domowej, opiekuńczej i reprodukcyjnej w budowaniu kapitalistycznego bogactwa, bowiem ta aktywność, będąca zazwyczaj udziałem kobiet, nie jest traktowana jako praca, nie wynagradza się jej zatem finansowo albo wynagradza bardzo źle ${ }^{53}$. Strajk kobiet trwa pokazuje walkę o wyższe zarobki i lepsze warunki pracy, została w nim także podkreślona pewna ciągłość tych bojów. Choć film zaczyna się i kończy obrazami z czarnych protestów, to - jak mówi Malinowska - działania pracownic poznańskich żłobków są częścią znacznie większego procesu: One nie wyszły po raz pierwszy na ulice $i$ to nie było tak, że to dopiero PiS zmobilizowat kobiety. (...) od 20 lat każda władza wprowadza regulacje, które sa dla kobiet niekorzystne, albo związane ze stużba zdrowia, albo zwiąane z cięciami budżetowymi, że zawsze kobiety niezależnie od tego, jaki mamy rząd, dostaja po dupie (W_MM).

Bohaterki dokumentu podkreślają także rodzące się w ramach wspólnych walk sojusze. Ważną rolę w ich działaniach odegrały rozmowy, dzielenie się wiedza, troskami, doświadczeniami, chęć wzajemnej pomocy i wspólnego działania. W scenie ukazującej rozmowę pięciu pracownic żłobków jedna z nich zwraca uwagę, że ignorowanie ich żądań dotyczących podwyżek (podobne wysuwają także pracownice innych miejskich placówek, centrów kultury, bibliotek) jest ignorowaniem żądań kobiet, bo to one zwykle pracują w tych miejscach. Oznacza to więc także dyskryminację ze względu na płeć. To poczucie krzywdy łączące kobiety jest ważnym krokiem w realizowaniu idei siostrzeństwa kształtującego się przez solidarne działania, wspieranie się i wspólną walkę. Jednostkowe doświadczenia zyskują kolektywne artykulacje, nabierając tym samym większej mocy i sprawczości: Formułowanie i wyrażanie społecznej świadomości scala grupe ludzi w konkretna "całość". Można zatem wyciagnać wniosek, że łaczac to, co indywidualne z tym, co strukturalne, doświadczenie zyskuje (...) przymiotnik "społeczne”, a jako doświadczenie społeczne posiada potencjat scalania grupy, a co za tym idzie również budowania wspólnotowości ${ }^{54}$. Tworzenie tej wspólnoty można analizować w obrębie kategorii siostrzeństwa, która choć zapożyczona jeszcze ze słownika drugiej fali feminizmu, współcześnie jest rozpatrywana przede wszystkim jako forma pewnej wrażliwości feministycznej, empatii i potrzeby wspólnej walki mimo różnic między tworzącymi dany sojusz osobami ${ }^{55}$. Strajk kobiet trwa jest właśnie taką opowieścią o siostrzeństwie ufundowanym na wspólnotowości batalii pracowniczych. Film jest także apelem o solidarność i wezwaniem do działania, podjęcia wysiłku zmiany warunków życia i sposobów ich definiowania.

\section{Dokument edukacyjny jako walka o nowe wartości w społeczeństwie}

Siłaczki to utrzymany w herstorycznym duchu, fabularyzowany dokument wyreżyserowany przez Martę Dzido i Piotra Śliwowskiego, opowiadający historię 
sufrażystek walczących o prawa kobiet w Polsce na przełomie XIX i XX w. Jego premiera odbyła się 28 listopada 2018 r., czyli w setną rocznicę przyznania kobietom praw wyborczych. Historyczna emancypacja Polek zostaje ukazana m.in. we fragmentach zainscenizowanych, w których słyszymy - znane dzięki dokumentom archiwalnym - słowa ówczesnych bohaterek. Jako pierwszy film dotyczący historii polskich sufrażystek Siłaczki stają się naszym zdaniem przede wszystkim dokumentem edukacyjnym.

Z filmu dowiadujemy się, że w dekrecie o ordynacji wyborczej do Sejmu Ustawodawczego podpisanym przez Józefa Piłsudskiego znalazła się jasna informacja, iż wyborca do Sejmu jest każdy obywatel państwa, bez różnicy płci, elementem kluczowym jest jednak zobrazowana przez twórców wieloletnia, niełatwa droga do równości. Droga ta to mrówcza praca wielu kobiet, które za pomocą różnych strategii i na różnych obszarach działały na rzecz emancypacji; wielorakie formy działania były zawsze bojownicze i wymagały odwagi. Łączyło je przekonanie wyrażone w 1911 r. podczas marszu krakowskich emancypantek przez polityczkę i sufrażystkę Zofię Daszyńską-Golińską: Praw się nie dostaje! Prawa się zdobywa w walce!

I tak poznajemy Kazimierę Bujwidowa, lobbującą za otwarciem dla kobiet uniwersytetów, która przy użyciu argumentu: Ludźmi jesteśmy i ludzkich praw żadamy! - uruchomiła lawinę listów kobiet do rektorów uczelni i doprowadziła do przyjęcia na studia pierwszych studentek. Film prezentuje również postać Marii Dulębianki, artystki i aktywistki społecznej, która w 1908 r. zdecydowała się wystartować w wyborach do Sejmu Galicyjskiego. W czasie gdy kobiety nie miały żadnych praw politycznych, na przekór wszystkiemu i wszystkim, prowadziła kampanię wyborczą pod hasłem - Odważmy się być wolnymi! W opowieści pojawia się też Zofia Nałkowska, pisarka, publicystka i przyszła posłanka, która nawoływała z kolei: Chcemy całego życia! - żądając równości pod względem obyczajowym.

Oprócz walki o równość płci w edukacji, polityce i sferze obyczajowej toczył się wtedy jeszcze jeden bój - ten o niepodległość kraju, którego nie było na mapie od ponad stu lat. W dokumencie widzimy, że - podobnie jak dziś - walkę o sprawy kobiet próbowano bagatelizować i odłożyć na później jako rzekomo mniej ważną od tej o tożsamość państwową. Jednak rodzime emancypantki, aktywistki i patriotki nie chciały wolnej Polski bez wolnych Polek. Pełne zapału i wytrwałości próbowały zatem nie dopuścić, by wolne państwo wywalczono dla obywateli, ale już nie dla obywatelek. Lobbując, nawołując, robiąc performanse polityczne, pisząc listy do najwyższych oficjeli, pozyskując sojuszników i organizując marsze, sufrażystki odniosły znaczący sukces w dwóch sferach: edukacyjnej i politycznej. Trzecia - obyczajowa - jest obszarem walki do dziś. Z filmu płynie jednak w tej kwestii ważny wniosek: oprócz tego że podkreśla wagę równości płci (nawet w obliczu tak istotnej walki niepodległościowej), pokazuje też, że działania ówczesnych emancypantek utorowały drogę ich następczyniom oraz że po to, by powstała wspólnota, potrzebna jest opowieść, która nie likwiduje sporów, konfliktów, niezgody, ale która tworzy dla nich ramy toczenia się i rozwiazywania pozwalające na wspólne bycie, a nie na dą̇enie do eliminacji jednej ze stron ${ }^{56}$. W takiej opowieści musi być słyszalny głos zdominowanych. W ten sposób staje się ona czymś na kształt „przeciw-historii”, którą Maria Solarska za Michelem Foucault nazywa władzy krytyka, atakiem na nia i rewindykacją ${ }^{57}$. 
W dokumencie przeszłość miesza się z teraźniejszością. Oprócz inscenizowanych ujęć odsyłających do przełomu XIX i XX w., fotografii i tekstów źródłowych z tego okresu, pojawiają się w nim sceny ukazujące potomkinie sufrażystek, badaczki oraz ekspertki, a także fragmenty współczesnych protestów, których celem są zmiany w sferze obyczajowej. Ujęcia kręcone na ulicach Warszawy czy Krakowa, m.in. podczas czarnych protestów, mieszają się z wiecami pierwszych emancypantek, co stanowi sugestię, że walka się nie skończyła. Słyszymy bliskie nam współcześnie okrzyki: Uwaga, uwaga, tu Obywatelki! czy: Solidarność nasza bronia, widzimy demonstrujących dziś ludzi z transparentami. W końcu, gdy widzimy delegację kobiet z trzech zaborów stukających parasolkami w okno dworku Piłsudskiego, możemy pomyśleć: „Nie składamy parasolek”. Historyczne zapętlenie pokazuje ciągłość walki o prawa kobiet, jej korzenie i ważność.

Solidarność transhistoryczna zostaje podkreślona za pomocą jeszcze jednego zabiegu formalnego. W postaci pierwszych emancypantek oprócz znanych aktorek (Maria Seweryn w roli Dulębianki) wcieliły się współczesne aktywistki i feministki, które nieodpłatnie zdecydowały się wziąć udział w nagraniach dzięki internetowej akcji Dzido i Śliwowskiego. Osoby identyfikujące się z przesłaniem filmu mogły zagrać rolę bojowniczek o prawa kobiet z epoki. Dzido w wywiadzie przywołuje słowa Marty Mazurek, która na poznańskiej premierze powiedziała: Przebieramy się, bo mamy za kogo. Film, prezentując losy emancypantek, które wpłynęły na bieg historii, wskazuje, że mamy bohaterki, do których możemy się dziś odwoływać. Opowieść o zmaganiach Polek przybliża tytułowe siłaczki i pozwala zrozumieć ciągłość procesu emancypacji, tworząc jednocześnie poczucie wspólnoty wartości, celów, misji. Rekonstrukcja minionych wydarzeń umożliwia ujrzenie we właściwym świetle lub wręcz odkrycie wielkiej herstorii oraz powoduje zmianę dotychczasowego porządku produkcji wiedzy przez zwrócenie uwagi na aspekt genderowy i związaną z nim hierarchię wartości - sposób, w jaki patrzymy na rzeczywistość, jest przecież uwikłany w relacje władzy, stanowi także znaczący element analizy feministycznej w filmie dokumentalnym ${ }^{58}$. Jego wymiaru dydaktycznego dopełniają głosy eksperckie wyjaśniające, jak interpretować zdarzenia. Jest to oczywiście narracja feministyczna, a dokument w pewnym sensie ją promuje. Owe głosy pośredniczek i pośredników historii powoduja że film traci trochę pod względem dramaturgicznym, ale dramaturgia nie jest tu najważniejsza. Rama edukacyjna pozwala zrozumieć proces ustanawiana praw kobiet i zbudować nowy rodzaj wspólnoty wiedzy.

Siłaczki to film, którego - w naszym odczuciu - zdecydowanie brakowało w polskiej kinematografii. Po pierwsze dlatego, że oddaje on cześć bohaterskiej walce sufrażystek, o której niewiele dowiadujemy się z innych tekstów kultury. Po drugie jego formuła - inscenizacje wydarzeń historycznych połączone $z$ wypowiedziami ekspertek i ekspertów - wzbogaca film o wymiar dydaktyczny, sprawiając, że może być on doskonałym materiałem edukacyjnym na zajęciach szkolnych i uniwersyteckich. Po trzecie, odkrywa i buduje historię działaczek społecznych walczących o równość płci. Współczesne aktywistki mogą utożsamić się z bohaterkami z przełomu wieków, zainspirować ich czynami, a przede wszystkim zrozumieć, że korzenie ich własnych działań sięgają w przeszłość (w szczególności odnosi się to do walki o liberalizację w sferze obyczajowej, podejmowanej już chociażby przez Irenę Krzywicką). 


\section{Zakończenie}

Feministyczne dokumenty filmowe, rozumiane przez nas jako rodzaj społecznego doświadczenia, są częścią ruchu feministycznego i mają moc sprawczą w walce o artykulację i zmianę dotychczasowych sposobów życia kobiet i osób z doświadczeniem życia jako kobieta. Ukazując ich historie, prawa, problemy i codzienność, rozwijają świadomość feministyczną, budują społeczność i postawy aktywistyczne, a wzywając do przeobrażeń rzeczywistości społecznej, odrzucają bezstronność na rzecz opowiedzenia się po stronie kobiecych podmiotów. Filmy te eksponują w końcu marginalizowany punkt widzenia, zaś ich twórcy rezygnują z niemożliwego do osiągnięcia obiektywizmu.

Feministyczna perspektywa jest w omawianym nurcie łączona m.in. z zacieraniem podziału na twórczynie/twórców i bohaterki. Ich relacja opiera się na uważności, empatii i wzajemności. Protagonistki się aktywnymi współautorkami filmu, które decydują o tym, co i jak zostanie przedstawione. Realizatorki/realizatorzy są z kolei częścią postulowanej w nim zmiany. Publikacja materiału filmowego współtworzy niejako historię ruchu feministycznego, film staje się jego częścia, narzędziem edukacyjno-interwencyjnym, pozwalającym pokazać niewidzialne, spychane na margines problemy i mogaccym spowodować realną zmianę. Interwencjonizm ma jeszcze jeden ważny wymiar. Autorki i autorzy filmów nawiązując bliskie relacje z bohaterkami, angażują się w ukazywaną sytuację, aby z kolei wpłynąć na poprawę ich warunków życia.

Feministyczne dokumenty filmowe to więc zdecydowanie "gatunek walczący" - o herstorię, prawa kobiet, ich widzialność, równouprawnienie i emancypację. W duchu humanistyki w działaniu ${ }^{59}$ filmy te badaja, pokazują i zmieniają rzeczywistość, „wyposażając” swoje bohaterki w moc sprawcza, dokonując ingerencji i interwencji w życiu matek, pracownic, lokatorek, stając się tym samym częścią praktyk feministycznych. Są to filmy zaangażowane i angażujące, oferujące spojrzenie z marginesu i odbierające jednoznaczność dominującym dyskursom nacechowanym genderowymi relacjami władzy. Przyglądając się feministycznym dokumentom i przyjmując feministycznie zorientowaną perspektywę badawcza, chciałyśmy zwrócić uwagę na strategie i wartości organizujące ich narracje oraz podkreślić ich znaczenie. Podejście twórcze, które proponują autorki i autor analizowanych filmów, uprzywilejowujące podmioty dotąd marginalizowane czy usuwane z obszaru społecznej widoczności, jest bowiem potrzebne, by móc nie tylko wpłynąć na bieżącą sytuację, ale też wyobrazić sobie zmianę i bardziej sprawiedliwą przyszłość.

${ }^{1}$ D. Rode, "To zdarza się nam". Polskie dokumenty feministyczne, w: Polski film dokumentalny w XXI wieku, red. T. Szczepański, M. Kozubek, PWSFTviT, Wydawnictwo Uniwersytetu Łódzkiego, Łódź 2016, s. 177.

${ }^{2}$ Nie są to oczywiście wszystkie dokumenty feministyczne, które powstały w tym czasie.
${ }^{3}$ R. Williams, The Analysis of Culture, w: Cultural Theory and Popular Culture: A Reader, red. J. Storey, University of Georgia Press, Athens 1998, s. 48.

${ }^{4}$ Pracą zdającą sprawę z form przechwytywania języka i posługiwania się przemocą symboliczną w kontekście płci jest książka Macieja Dudy pt. Dogmat ptci. Polska wojna 
z gender, Wydawnictwo Naukowe Katedra, Gdańsk 2016.

${ }^{5}$ Czy też kryzysem azylowym - w tym sformułowaniu nacisk jest położony na przyczyny kryzysu leżące w europejskiej polityce azylowej. Nazwa ta zdejmuje odpowiedzialność za kryzys z osób, które próbowały i próbują dotrzeć do Europy. Zob. m.in. P. Kingsley, Nowa Odyseja. Opowieść o kryzysie uchodźczym w Europie, Wydawnictwo KP, Warszawa 2017. Dziękujemy Kamilowi Kuhrowi za zwrócenie uwagi na tę kwestię.

${ }^{6}$ Odrzucenie obiektywizmu nie musi być zresztą właściwością jedynie feministycznego dokumentu. Zob. M. Przylipiak, Poetyka kina dokumentalnego, Wydawnictwo Uniwersytetu Gdańskiego, Gdańsk 2000, s. 43-53.

${ }^{7}$ E. McGarry, Documentary, Realism E Women's Cinema, „Women and Film” 1975, nr 2, s. 50.

${ }^{8}$ N. Abercrombie, S. Lash, B. Longhurst, Przedstawienie popularne: przerabianie realizmu, tłum. E. Mrowczyk-Hearfield, w: Odkrywanie modernizmu. Przekłady i komentarze, red. R. Nycz, Universitas, Kraków 2004, s. 387.

9 Zob. T. de Lauretis, Estetyka a teoria feministyczna: ponowne przemyślenie kobiecego kina, tłum. A. Krawczyk, „Panoptikum” 2005, nr 4 czy tejże, Technologies of Gender: Essays on Theory, Film, and Fiction, Indiana University Press, Bloomington - Indianapolis 1987, s. 18$-32$.

${ }^{10}$ Zob. M. Talarczyk-Gubała, Biały mazur. Kino kobiet w polskiej kinematografii, Galeria Miejska Arsenał, Poznań 2013.

${ }^{11}$ Zob. M. Radkiewicz, "Wtadczynie spojrzenia”. Teoria filmu a praktyka reżyserek i artystek, Ha art.!, Kraków 2010.

12 Zob. N. Fraser, Drogi feminizmu. Od kapitalizmu państwowego do neoliberalnego kryzysu, tłum. A. Weseli, Wydawnictwo KP, Warszawa 2014.

${ }^{13}$ Zob. S. Federici, Prekariat. Perspektywa feministyczna, Biblioteka Online Think Tanku Feministycznego 2010, http://www.ekologiasztuka.pl/pdf/f0096federici.pdf (dostęp: 1.10.2019).

${ }^{14}$ Zob. J. Wallach Scott, Gender jako przydatna kategoria analizy historycznej, tłum. A. Czarnacka, Biblioteka Online Think Tanku Feministycznego 2009, http://www.ekologiasztuka.pl/pdf/f0064scott.pdf (dostęp: 1.10.2019).

15 Zob. M. Solarska, S/Przeciw-historia. Wymiar krytyczny historii kobiet, Oficyna Wydawnicza Epigram, Bydgoszcz 2011; tejże, Poznanie historyczne a czas historyczny, w: M. Solarska, M. Bugajewski, Doświadczanie przeszłości. Poz- nanie historyczne wobec pluralizmu czasu historycznego, Instytut Historii UAM, Poznań 2018.

${ }^{16}$ Wywiad z Magdą Malinowską został przeprowadzony 24 stycznia 2019 r. w Poznaniu; odniesienia do niego są oznaczone dalej jako (W_MM); wywiad z Martą Dzido i Piotrem Śliwowskim odbył się 20 lutego 2019 r. w Warszawie; dalej jako (W_MDPŚ).

${ }^{17}$ R. Edwards, M. Mauthner, Ethics and Feminist Research: Theory and Practice, w: Ethics in Qualitative Research, red. T. Miller, M. Birch, M. Mauthner, J. Jessop, Sage, London 2002, s. $19-20$.

${ }^{18}$ N. K. Denzin, The Reflexive Interview and a Performative Social Science, "Qualitative Research" 2001, t. 1, nr 1, s. 29.

${ }^{19}$ V. Olesen, Feministyczne badania jakościowe u progu millenium. Zarys $i$ wyzwania, tłum. M. Bobako, w: Metody badań jakościowych, red. N. K. Denzin, Y. S. Lincoln, PWN, Warszawa 2009, s. 343.

${ }^{20}$ J. Lesage, The Political Aesthetics of Feminist Documentary Film, "Quarterly Review of Film Studies" 1978, t. 3, nr 4, s. 507-523.

${ }^{21}$ Zob. L. Mulvey, Przyjemność wzrokowa a kino narracyjne, tłum. J. Mach, w: Panorama wspótczesnej myśli filmowej, red. A. Helman, Universitas, Kraków 1992.

${ }^{22}$ C. Johnston, Kino kobiece jako kino buntu, tłum. A. Helman, „Film na Świecie” 1991, nr 384, s. $13-21$.

${ }^{23}$ Kino kobiet nie musi być tożsame $\mathrm{z}$ kinem feministycznym. O znaczącej różnicy między nimi pisze we wprowadzeniu do książki Biały mazur Monika Talarczyk-Gubała, zob. M. Talarczyk-Gubała, dz. cyt., s. 19-20.

${ }^{24}$ Tamże.

${ }^{25}$ E. McGarry, dz. cyt.

${ }^{26}$ J. Walker, D. Waldman, Introduction, w: Feminism and Documentary, red. D. Waldman, J. Walker, University of Minnesota Press, Minneapolis 1999, s. 1-35.

${ }^{27} \mathrm{~J}$. Lesage, dz. cyt.

${ }^{28}$ S. Scarparo, B. Luciano, The Personal Is Still Political: Films ,by and for Women" by the New „documentariste”, "Italica” 2010, t. 87, nr 3, s. $488-503$.

${ }^{29}$ Przyglądając się udziałowi twórczyń w produkcjach filmowych, zauważamy, że największy ich odsetek pracuje na obszarze filmu dokumentalnego (27\% w 2019 r.). Por. M. M. Lauzen, The Celluloid Ceiling: Behindthe-Scenes Employment of Women on the Top 100, 250, and 500 Films of 2019, Center for the Study of Women in Television and Film, San Diego State University - San Diego 2019, 
https://womenintvfilm.sdsu.edu/wp-content/uploads/2020/01/2019_Celluloid_Ceiling_Report.pdf (dostęp: 1.05.2020).

${ }^{30}$ Jest to sformułowanie, którym posługuje się Martha M. Lauzen badająca kwestię udziału kobiet $\mathrm{w}$ branży filmowej i publikująca raporty o takim samym tytule. Zob. tamże.

${ }^{31}$ M. Maciejewska, M. Malinowska, Badania zaangażowane, niezależne media $i$ ruchy społeczne, czyli jak powstawał film "Strajk matek", Biblioteka Online Think Tanku Feministycznego, http://www.ekologiasztuka.pl/pdf/f0121_maciejewska_malinowska.pdf (dostęp: 1.10.2019), s. 3.

${ }^{32} \mathrm{~S}$. Kemmis, Teoria krytyczna i uczestniczace badania w działaniu, tłum. K. Liszka, w: Badania $w$ działaniu. Pedagogika i antropologia zaangażowane, red. H. Červinková, B. D. Gołębniak, Wydawnictwo Naukowe Dolnośląskiej Szkoły Wyższej, Wrocław 2010, s. 87.

${ }^{33}$ Tamże.

${ }^{34}$ N. Nicol, Telling Our Stories: Envisioning Participatory Documentary, w: Envisioning Global LGBT Human Rights, red. N. Nicol, A. Jjuuko, R. Lusimbo i in., School of Advanced Study - University of London - Institute of Commonwealth Studies, London 2018, s. 379.

${ }^{35}$ M. Maciejewska, M. Malinowska, dz. cyt., s. 4 .

${ }^{36}$ M. Grabowska, Zerwana genealogia. Działalność społeczna i polityczna kobiet po 1945 roku a wspótczesny polski ruch kobiet, Wydawnictwo Naukowe Scholar, Warszawa 2018, s. 103-109.

${ }^{37}$ M. Maciejewska, M. Malinowska, dz. cyt., s. 4.

${ }^{38} \mathrm{~W}$ tym kontekście pojawiają się m.in. takie wątpliwości: czy jest to strategia, która polega na dotarciu do wszystkich zainteresowanych w prezentowaniu określonego konfliktu?; czy jest to w ogóle możliwe, żeby nikogo nie pominać i sprawiedliwie podzielić uwagę?; czy jest to właściwe w sytuacji, kiedy jedna z grup interesu została wyposażona w dużo większy kapitał kulturowy i ekonomiczny a inna w mniejszy?; czy obie grupy mają wówczas szansę zaprezentować jednakowo swoje racje?

${ }^{39}$ J. Ruby, Obraz odbity - refleksywność i film dokumentalny, tłum. D. Rode, M. Pieńkowski, Z. Pieńkowski, w: Metody dokumentalne w filmie, red. D. Rode, M. Pieńkowski, Wydawnictwo Biblioteki PWSFTviT, Łódź 2013, s. 230.

${ }^{40}$ N. Fraser, dz. cyt., s. 264-266.

${ }^{41}$ Omawiany tu film, jako że pokazuje historie kobiet, może być ponadto rozpatrywany z perspektywy krytycznej historiografii. Ujawniający się w niej „potencjał rewoltujący" Maria Solarska określa jako zdolność do inspiracji społecznej lub indywidualnej niezgody na zastany świat/porządek społeczny. M. Solarska, S/Przeciw-historia... dz. cyt., s. 71.

${ }^{42}$ S. Kuźma-Markowska, Herstory (herstoria), w: Encyklopedia gender. Płeć w kulturze, red. M. Rudaś-Grodzka i in., Wydawnictwo Czarna Owca, Warszawa 2014, s. 182-187.

${ }^{43}$ Zob. E. Oleksy, "Women, Don't Interfere with Us; We're Fighting for Poland": Polish Mothers and Transgressive Others, w: Women, Activism and Social Change, red. M. Mikula, Routledge, London - New York 2005; A. Graff, Świat bez kobiet, Wydawnictwo W.A.B., Warszawa 2001; A. Graff, Claiming the Shipyard, the Cowboy Hat, and the Anchor for Women: Polish Feminism's Dialogue and Struggle with National Symbolism, ,East European Politics and Societies and Culture" 2019, t. 33, nr 2; M. Dzido, Kobiety Solidarności, Świat Książki, Warszawa 2016.

${ }^{44}$ D. Haraway, Wiedze usytuowane. Kwestia nauki w feminizmie i przywilej ograniczonej/czẹściowej perspektywy, tłum. A. Czarnacka, Biblioteka Online Think Tanku Feministycznego, 2008, http://www.ekologiasztuka.pl/pdf/f0062haraway1988.pdf (dostęp: 1.09.2019), s. 19.

45 Zob. J. Jankowska, Portrety niedokończone. Rozmowy z twórcami "Solidarności" 1980-1981, Biblioteka Więzi, Warszawa 2003.

${ }^{46}$ B. Nichols, Typy filmu dokumentalnego, tłum. M. Heberle, D. Rode, w: Metody dokumentalne w filmie, dz. cyt., s. 33 .

${ }^{47} \mathrm{O}$ kobietach, które tworzyły „Solidarność", pisze również amerykańska badaczka Shana Penn, która analizuje przemilczaną historię udziału kobiet w podziemiu i mediach opozycyjnych. Zob. S. Penn, Sekret "Solidarności". Kobiety, które pokonaty komunizm w Polsce, tłum. M. Antosiewicz, Wydawnictwo W.A.B., Warszawa 2014.

${ }^{48}$ Niektóre kobiety wypowiadające się w Strajku matek były tymczasowymi pracownicami w specjalnej strefie ekonomicznej pod Wałbrzychem. W filmie słyszymy ich skargi na obowiązujące tam niepewne warunki pracy. Malinowska i Maciejewska chciały same zatrudnić się w strefie, by poznać tę sytuację, zorganizować tam związek zawodowy i zrealizować o tym dokument. Ostatecznie zatrudniła się tylko Maciejewska. Obie autorki zrealizowały jednak film dokumentalny Specjalne strefy wyzysku (2013).

${ }^{49}$ Chodzi o demonstrację "Chleba zamiast igrzysk" zorganizowaną w czerwcu 2012 r. 
w Poznaniu w trakcie Mistrzostw Europy w piłce nożnej mężczyzn przeciwko wydatkom poniesionym na organizację tej imprezy kosztem m.in. polityki społecznej, opieki zdrowotnej, edukacji itd. - tych elementów budżetu publicznego, których dysfunkcyjność odczuwają szczególnie kobiety. Zob. https://chlebazamiastigrzysk.wordpress.com/.

${ }^{50}$ Zob. raport Bunt kobiet. Czarne Protesty i Strajki Kobiet, red. E. Korolczuk, B. Kowalska, J. Ramme, C. Snochowska-Gonzalez, Europejskie Centrum Solidarności, Gdańsk 2018.

51 Zob. S. Chant, Feminizacja biedy $i$ "feminizowanie" programów walki z ubóstwem: czy już czas na rewizję? w: Kobiety, gender i globalny rozwój. Wybór tekstów, red. N. Visvanathan i in., Polska Akcja Humanitarna, Warszawa 2012; E. Charkiewicz, Kobiety i ubóstwo - widzialna ręka neoliberalnego państwa, Biblioteka Online Think Tanku Feministycznego 2010, http://www.ekologiasztuka.pl/pdf/f0102cha rkiewicz2010.pdf (dostęp: 15.07.2019).

${ }^{52}$ B. Nichols, dz. cyt., s. 21.

${ }^{53}$ S. Federici, dz. cyt., s. 9.

${ }^{54}$ A. Ostaszewska, Czarne protesty. Doświadczenia społeczne jako podstawa "communitas" kobiet, ,Pedagogika Społeczna” 2017, nr 4 (66), s. 126.
${ }^{55}$ Zob. K. Sikorska, Siostrzeństwo i jego dyskursywne użycia, "Acta Universitatis Lodziensis. Folia Sociologica" 2019, nr 70, s. 39-58.

${ }^{56}$ M. Solarska, Poznanie historyczne a czas historyczny, dz. cyt., s. 67.

${ }^{57}$ M. Solarska, S/Przeciw-historia... dz. cyt., s. 53. Badaczka rozpatrując ideę „przeciwhistorii" zwraca też uwagę, że opowieść przeciw-historii jest (...) radykalnie przeciwstawna wobec tradycyjnego dyskursu historycznego zamiast umacniać władzę suwerena, kwestionuje ja $i$ wskazuje na jej niesprawiedliwość, rozbija jej jedność, w myśl której zwycięstwa jednych nie byty klęskami drugich, lecz przyczynkami do chwały suwerena. Tamże, s. 53.

${ }^{58}$ D. Olivieri, Haunted by Reality: Toward a Feminist Study of Documentary Film. Indexicality, Vision and the Artifice, All Print, Utrecht 2012, s. $53-58$

${ }^{59}$ Zob. E. Domańska, Sprawiedliwość epistemiczna w humanistyce zaangażowanej, w: Nowa humanistyka. Zajmowanie pozycji, negocjowanie autonomii, red. P. Czapliński i in., Instytut Badań Literackich PAN, Warszawa 2017, s. 51-70; Video for Change: A Guide for Advocacy and Activism, red. S. Gregory i in., Pluto Press, London 2005; S. Speed, At the Crossroads of Human Rights and Anthropology: Toward a Critically Engaged Activist Research, ,American Anthropologist" 2006, t. 108, nr 1, s. 66-76.
Karolina Sikorska

Sandra Frydrysiak
Kulturoznawczyni, doktorka nauk humanistycznych, badaczka praktyk artystycznych, kuratorka; adiunktka w Instytucie Nauk o Kulturze Uniwersytetu Mikołaja Kopernika w Toruniu. Autorka książki „Kobiece” gatunki telewizyjne. Geneza i kulturowe przeobrażenia (2018), redaktorka i współredaktorka publikacji naukowych, m.in. „Antywzorce” we zsspółczesnej sztuce i kulturze wizualnej (2018). Jej zainteresowania badawcze dotyczą kultury wizualnej, feminizmu i edukacji kulturowej.

Doktorka nauk humanistycznych, kulturoznawczyni i socjolożka pracująca naukowo na obszarach gender studies, dance studies i new media studies. Adiunktka w Instytucie Nauk Humanistycznych SWPS Uniwersytetu Humanistycznospołecznego w Warszawie. Wykładowczyni Joint European Master's Degree in Women's and Gender Studies: GEMMA na Uniwersytecie Łódzkim. Autorka książki Taniec w sprzężeniu nauk $i$ technologii. Nowe perspektywy w badaniach tanca (2017). Członkini EuroGender Network (w ramach European Institute for Gender Equality). 


\section{Bibliografia}

Abercrombie, N., Lash, S., Longhurst, B. (2004). Przedstawienie popularne: przerabianie realizmu (tłum. E. Mrowczyk-Hearfield). W: R. Nycz (red.), Odkrywanie modernizmu. Przekłady i komentarze (ss. 381-416). Kraków: Universitas.

Chant, S. (2012). „Feminizacja biedy” i „feminizowanie” programów walki z ubóstwem: czy już czas na rewizję? (thum. A. Czarnacka, H. Jankowska, M. Kowalska). W: N. Visvanathan, L. Duggan, N. Wiegersma, L. Nisonoff (red.), Kobiety, gender i globalny rozwój. Wybór tekstów (ss. 211-233). Warszawa: Polska Akcja Humanitarna.

Charkiewicz, E. (2010). Kobiety i ubóstwo - widzialna ręka neoliberalnego państwa. Biblioteka Online Think Tanku Feministycznego. http://www.ekologiasztu$\mathrm{ka.pl} / \mathrm{pdf} /$ fo1O2charkiewicz2010.pdf

Denzin, N. K. (2001). The Reflexive Interview and a Performative Social Science. Qualitative Research, 1 (1), ss. 23-46.

Domańska, E. (2017). Sprawiedliwość epistemiczna w humanistyce zaangażowanej. W: P. Czapliński, R. Nycz i in. (red.), Nowa humanistyka. Zajmowanie pozycji, negocjowanie autonomii (ss. 51-70). Warszawa: Instytut Badań Literackich PAN.

Duda, M. (2016). Dogmat płci. Polska wojna z gender. Gdańsk: Wydawnictwo Naukowe Katedra.

Dzido, M. (2016). Kobiety Solidarności. Warszawa: Świat Książki.

Edwards, R., Mauthner, M. (2012). Ethics and Feminist Research: Theory and Practice. W: T. Miller, M. Birch, M. Mauthner, J. Jessop (red.), Ethics in Qualitative Research (ss. 14-31). London: Sage.

Federici, S. (2010). Prekariat: perspektywa feministyczna (tłum. M. Skóra). Biblioteka Online Think Tanku Feministycznego. http://www.ekologiasztuka.pl/pdf/foog6federici.pdf

Fraser, N. (2014). Drogi feminizmu. Od kapitalizmu państwowego do neoliberalnego kryzysu (thum. A. Weseli). Warszawa: Wydawnictwo Krytyki Politycznej.

Grabowska, M. (2018). Zerwana genealogia. Działalność społeczna i polityczna kobiet po 1945 roku a respółczesny polski ruch kobiet. Warszawa: Wydawnictwo Naukowe Scholar.

Graff, A. (2001). Śziat bez kobiet. Pteć w polskim życiu publicznym. Warszawa: Wydawnictwo W.A.B.

Graff, A. (2019). Claiming the Shipyard, the Cowboy Hat, and the Anchor for Women: Polish Feminism's Dialogue and Struggle with National Symbolism. East European Politics and Societies and Cultures, 33 (2), ss. 472-496.

Gregory, S., Caldwell, G., Avni, R., Harding, T. (red.) (2005), Video for Change: A Guide for Advocacy and Activism Edited. London: Pluto Press.

Haraway, D. (2009). Wiedze usytuowane. Kwestia nauki w feminizmie i przyzilej ograniczonej/czessciowej perspektywy (thum. A. Czarnacka). Biblioteka Online Think Tanku Feministycznego. http://www.ekologiasztuka.pl/pdf/foo62haraway1988.pdf

Jankowska, J. (2003). Portrety niedokończone. Rozmozy z twórcami „Solidarności” 19801981. Warszawa: Biblioteka Więzi.

Johnston, C. (1991). Kino kobiece jako kino buntu (thum. A. Helman). Film na Śziecie, (384), ss. 13-21.

Kemmis, S. (2010). Teoria krytyczna i uczestniczące badania w działaniu (thum. K. Liszka). W: H. Červinková, B. D. Gołębniak (red.), Badania w działaniu. Pedagogika i an- 
tropologia zaangażowane (s. 45-88). Wrocław: Wydawnictwo Naukowe Dolnośląskiej Szkoły Wyższej.

Kingsley, P. (2017). Nowa Odyseja. Opowieść o kryzysie uchodźczym w Europie (thum. A. Paszkowska). Warszawa: Wydawnictwo Krytyki Politycznej.

Korolczuk, E., Kowalska, B., Ramme, J., Snochowska-Gonzalez, C. (red.) (2018). Bunt kobiet. Czarne Protesty i Strajki Kobiet. Gdańsk: Europejskie Centrum Solidarności.

Kuźma-Markowska, S. (2014). Herstory (herstoria). W: M. Rudaś-Grodzka i in. (red.), Encyklopedia gender. Płeć w kulturze (ss. 182-187). Warszawa: Wydawnictwo Czarna Owca.

Lauretis, T. de (1987). Technologies of Gender: Essays on Theory, Film, and Fiction. Bloomington - Indianapolis: Indiana University Press.

Lauretis, T. de (2005). Estetyka a teoria feministyczna: ponowne przemyślenie kobiecego kina (thum. A. Krawczyk). Panoptikum, 11 (4), ss. 18-32.

Lauzen, M. M. (2019). The Celluloid Ceiling: Behind-the-Scenes Employment of Women on the Top 100, 250, and 500 Films of 2019. San Diego: Center for the Study of Women in Television and Film - San Diego State University. https:/womenintvfilm.sdsu.edu/wp-content/uploads/2020/o1/2019_Celluloid_Ceiling_Report.pdf

Lesage, J. (1978). The Political Aesthetics of Feminist Documentary Film. 2uarterly Review of Film Studies, 3 (4), ss. 507-523.

Maciejewska, M., Malinowska M. (2013). Badania zaangażowane, niezależne media i ruchy społeczne, czyli jak powstawat film „Strajk matek”. Biblioteka Online Think Tanku Feministycznego.http://www.ekologiasztuka.pl/pdf/fo121_maciejewska_malinowska.pdf

McGarry, E. (1975). Documentary, Realism \& Women's Cinema. Women and Film, 2 (7), SS. 50-59.

Mulvey, L. (1992). Przyjemność wzrokowa a kino narracyjne (tłum. J. Mach). W: A. Helman (red.), Panorama wospółczesnej myśli filmowej (ss. 95-107). Kraków: Universitas.

Nichols, B. (2013). Typy filmu dokumentalnego (thum. M. Heberle, D. Rode). W: D. Rode, M. Pieńkowski (red.), Metody dokumentalne w filmie (ss. 13-43). Łódź: Wydawnictwo PWSFTviT.

Nicol, N. (2018). Telling Our Stories: Envisioning Participatory Documentary. W: N. Nicol, A. Jjuuko, R. Lusimbo i in. (red.), Envisioning Global LGBT Human Rights (ss. 371-401). London: School of Advanced Study - University of London - Institute of Commonwealth Studies.

Oleksy, E. (2005). „Women, Don’t Interfere with Us; We're Fighting for Poland”: Polish Mothers and Transgressive Others. W: M. Mikula (red.), Women, Activism and Social Change (ss. 263-270). London - New York: Routledge.

Olesen, V. (2009). Feministyczne badania jakościowe u progu millenium. Zarys i wyzwania (tłum. M. Bobako). W: N. K. Denzin, Y. S. Lincoln (red.), Metody badań jakościowych (t. 1, ss. 341-398). Warszawa: PWN.

Olivieri, D. (2012). Haunted by Reality: Toward a Feminist Study of Documentary Film. Indexicality, Vision and the Artifice. Utrecht: All Print.

Ostaszewska, A. (2017). Czarne protesty. Doświadczenia społeczne jako podstawa „communitas” kobiet. Pedagogika Społeczna, 66 (4), ss. 117-132.

Penn, S. (2014). Sekret „Solidarności”: kobiety, które pokonały komunizm w Polsce (thum. M. Antosiewicz). Warszawa: Wydawnictwo W.A.B. 
Przylipiak, M. (2000). Poetyka kina dokumentalnego. Gdańsk: Wydawnictwo Uniwersytetu Gdańskiego.

Radkiewicz, M. (2010). „Władczynie spojrzenia”. Teoria filmu a praktyka reżyserek $i$ artystek. Kraków: Ha art.!

Rode, D. (2016). „To zdarza się nam”. Polskie dokumenty feministyczne. W: T. Szczepański, M. Kozubek (red.), Polski film dokumentalny w XxI wieku (ss. 163-177). Łódź: PWSFTviT, Wydawnictwo Uniwersytetu Łódzkiego.

Ruby, J. (2013). Obraz odbity - refleksywność i film dokumentalny (tłum. D. Rode, M. Pieńkowski, Z. Pieńkowski). W: D. Rode, M. Pieńkowski (red.), Metody dokumentalne w filmie (ss. 215-231). Łódź: Wydawnictwo Biblioteki PWSFTviT.

Scarparo, S., Luciano, B. (2010). The Personal Is Still Political: Films „by and for Women” by the New „documentariste”, Italica, 87 (3), ss. 488-503.

Sikorska, K. (2019). Siostrzeństwo i jego dyskursywne użycia. Acta Universitatis Lodziensis. Folia Sociologica, (70), ss. 39-58.

Solarska, M. (2011). S/Przeciw-historia. Wymiar krytyczny historii kobiet. Bydgoszcz: Oficyna Wydawnicza Epigram.

Solarska, M. (2018). Poznanie historyczne a czas historyczny. W: M. Solarska, M. Bugajewski, Dośziadczanie przeszłości. Poznanie historyczne wobec pluralizmu czasu historycznego (ss. 13-74). Poznań: Instytut Historii UAM.

Speed, S. (2006). At the Crossroads of Human Rights and Anthropology: Toward a Critically Engaged Activist Research. American Anthropologist, 108 (1), ss. 66-76.

Talarczyk-Gubała, M. (2013). Biały mazur. Kino kobiet wo polskiej kinematografii. Poznań: Galeria Miejska Arsenał.

Walker, J., Waldman, D. (1999). Introduction. W: D. Waldman, J. Walker (red.), Feminism and Documentary (ss. 1-35). Minneapolis: University Of Minnesota Press.

Wallach Scott, J. (2009). Gender jako przydatna kategoria analizy historycznej (thum. A. Czarnacka). Biblioteka Online Think Tanku Feministycznego. http://www.ekologiasztuka.pl/pdf/foo64scott.pdf

Williams, R. (1998). The Analysis of Culture. W: J. Storey (red.), Cultural Theory and Popular Culture: A Reader (s. 48-56). Athens: University of Georgia Press.

Keywords:

feminist

documentary film;

in-depth interview;

interventionist film;

herstory;

sisterhood;

educational film

\section{Abstract \\ Karolina Sikorska, Sandra Frydrysiak}

\section{On the Side of Their Heroines: Feminist Documentary} Film in Poland in the Second Decade of the $21^{\text {st }}$ Century

The authors look from a feminist perspective at four Polish documentary films: Strajk matek (Mothers on Strike, dir. M. Maciejewska, M. Malinowska, 2011), Solidarność wedtug kobiet (Solidarity According to Women, dir. M. Dzido, P. Śliwowski, 2014), Strajk kobiet trwa (The Women's Strike Continues, dir. M. Malinowska, 2018), and Siłaczki (Women Power, dir. M. Dzido, P. Śliwowski, 2018). They analyse these productions, recognizing in them a call to transform social reality, and treating them as examples of a "fighting genre", which is perceived in the article as a kind of social expe- 
rience, foregrounding the necessity for solidarity in the struggle for a better life, for visibility in the public space, and for the recognition of values, histories or practices relevant to particular women's communities. Reflecting on the various dimensions of the feminist documentary film interventionist, herstoric, committed, and educational - the authors show how working on a film also becomes a form of active support for the Polish women's movement. 